http://dx.doi.org/10.18778/8088-642-1.09

Anna Jarkiewicz*

\title{
Możliwości działania pedagoga społecznego w obszarze problematyki chorób i zaburzeń psychicznych - na przykladzie psychiatrii środowiskowej
}

\section{Wstęp}

Jako studentka pedagogiki społecznej często spotykałam się z pytaniem znajomych: „kim właściwie jest pedagog społeczny?”. Większość z nich automatycznie wiązała wybrany przeze mnie kierunek studiów z pracą z dziećmi. Każdego musiałam więc wyprowadzać z błędu, próbując wyjaśnić, że pedagog społeczny to nie to samo, co wychowawca w przedszkolu ani tym bardziej - nauczyciel w szkole. Najtrudniejszy dla nich do zrozumienia był jednak fakt, że pedagog społeczny wcale nie musi pracować z dziećmi. Z powyższymi wątpliwościami stykałam się nie tylko ja, lecz także inne osoby z mojego rocznika. Obecnie, z ciekawości zadaję moim studentom pytanie, jakie są reakcje ich znajomych, kiedy dowiadują się, że studiują pedagogikę społeczną. Zadziwiające jest to, że niewiele w tej kwestii się zmieniło. Większość osób nadal nie ma pojęcia, kim jest pedagog społeczny i czym się zajmuje. Jest to dość smutna sprawa, biorąc pod uwage tradycję tej (sub)dyscypliny naukowej. Trudno się jednak dziwić, gdy nasi absolwenci nie są zatrudniani na stanowisku pedagog społeczny ${ }^{1}$, bo takie w tej chwili nie istnieje, ale np. jako wychowawca, kurator czy asystent rodziny.

W niniejszym tekście chciałabym przybliżyć jedną z wielu możliwości pracy dla pedagoga społecznego oraz wskazać na perspektywy, jakie niesie ze sobąjego

* Uniwersytet Łódzki, Wydział Nauk o Wychowaniu, Katedra Pedagogiki Społecznej.

${ }^{1}$ Warto $\mathrm{w}$ tym miejscu dodać, że $\mathrm{w}$ Polsce nie istnieje na rynku pracy stanowisko pracy pedagog społeczny (w odróżnieniu od niektórych państw europejskich, takich jak np. Niemcy czy Łotwa), co z pewnością przyczynia się do słabej rozpoznawalności tej profesji. Pedagodzy społeczni do roku 2012 często byli zatrudniani jako pracownicy socjalni, co nie jest już możliwe po zmianie ustawy traktującej o zawodzie pracownika socjalnego. 
zatrudnienie w instytucjach typu szpital psychiatryczny, oddziały dzienne czy np. środowiskowe domy samopomocy dla osób z problemami psychicznymi. Celem artykułu jest podkreślenie ważności i zwrócenie uwagi na rolę pedagoga społecznego w polu problematyki związanej z zaburzeniami psychicznymi. Warto dodać, że aktualnie nie istnieje na rynku pracy takie stanowisko jak pedagog społeczny, co z pewnością przyczynia się do słabej rozpoznawalności tej profesji. Pedagodzy społeczni, od roku 2012, czyli do momentu wejścia ustawy, byli zatrudniani jako pracownicy socjalni, co obecnie nie jest już możliwe. Zostawiając w tej chwili na boku dyskusję na temat jakości i sensowności tych zmian, pragnę omówić możliwości, kompetencje i ograniczenia pedagoga społecznego zatrudnionego w instytucjach o profilu psychiatrycznym. Pozostaję jednocześnie z nadzieją, że w niedalekiej przyszłości ,pedagog społeczny” pojawi się jako stanowisko, a nie tylko kierunek studiów.

Niestety, w tekście nie zabraknie tzw. „myślenia życzeniowego”, ponieważ opisywany przeze mnie obszar jest zdominowany przez profesję lekarską, której reprezentanci nierzadko deprecjonują dokonania i możliwości przedstawicieli innych specjalizacji.

Podstawą prezentowanych wniosków są własne doświadczenia w pracy w tego typu instytucjach ${ }^{2}$ oraz refleksja nad praktyką w obszarze psychiatrycznym.

\section{Pedagog społeczny - czyli kto?}

Pedagog społeczny, w instytucjach adresujących pomoc do osób z zaburzeniami psychicznymi, przed zmianą regulacji dotyczących zatrudniania na stanowisku pracownika socjalnego, był zazwyczaj angażowany do tej roli. Był odpowiedzialny za kwestie socjalno-bytowe. W praktyce oznacza to najczęściej, że zajmuje się pomocą $\mathrm{w}$ nabyciu przez pacjenta uprawnień do różnych świadczeń finansowych (typu renta) bądź opiekuńczych. Poprzez złożoną biurokrację i masę dokumentów, które towarzyszą tym działaniom, wielu psychiatrów, psychologów, pielęgniarek kojarzyło pracownika socjalnego z osobą, która ma kompetencje i możliwości, by zajmować się tylko tego typu sprawami. Sam Jankowski (1975) przyznał, że przez wiele lat identyfikował pracowników socjalnych jako „Panie od papierków", których istota pracy pozostawała dla niego tajemnicą. W instytucjach o profilu psychiatrycznym pokłosie tego myślenia jest nadal żywe, co w znaczący sposób degraduje rolę pedagoga społecznego i możliwości rozwoju pracy socjalnej/społecznej realizowanej w tym obszarze działania. W przypadku

${ }^{2}$ Zanim podjęłam pracę na Uniwersytecie byłam stażystką w dziennym oddziale psychiatrycznym, ponadto przez wiele lat pracowałam jako opiekunka specjalistyczna dla osób z zaburzeniami psychicznymi, a w okresie studiów byłam wolontariuszką w jednym ze środowiskowych domów samopomocy dla osób chorujących na schizofrenię. 
wspomnianego Jankowskiego zmiana w sposobie postrzegania „Pań od papierków" była związana z osobistymi doświadczeniami, które przekształciły jego tok rozumowania nie tylko w kwestiach związanych z pracą społeczna, lecz także generalnie z cała psychiatria, co jest odzwierciedlone w tytule jego publikacji $O d$ psychiatrii biologicznej do humanistycznej.

Od czasów Jankowskiego w obszarze instytucji psychiatrycznych zaszło wiele zmian, ale trudno mówić o spektakularnych przemianach w sprawie roli pracy społecznej. Nadrzędną pozycję w polskiej scenerii psychiatrycznej w prowadzeniu tzw. „przypadku” pełni lekarz psychiatra, co mocno przeciaga linę w stronę podejścia medycznego. Na nieco lepszej pozycji od pedagoga społecznego jest psycholog, którego praca, jak wynika z moich obserwacji, nazbyt często zamiast eksponować i przemycać wątki humanistyczne, sympatyzuje z medycyną i idzie w kierunku klinicznym³ ${ }^{3}$. Wszystko to sprawia, że podejścia środowiskowe, których naturalnym reprezentantem jest pedagog społeczny i dokonywana przez niego społeczna diagnoza, która powinna być ukierunkowana na zrozumienie przeżyć i doświadczeń pacjenta, jest bagatelizowana i nie jest traktowana jako klucz do rozszyfrowania obecnej sytuacji osób zgłaszających się po pomoc. Schock, Clay i Cipani ${ }^{4}$ zanotowali wiele przypadków, w których trafna diagnoza niemedyczna pozwoliła na przeprowadzenie skutecznej interwencji i minimalizację bądź całkowite wyeliminowanie zachowań symptomatycznych u pacjentów ze zdiagnozowaną psychozą. Jeden z nich dotyczy mężczyzny (42 lata), u którego rozpoznana została schizofrenia paranoidalna. Miał on za sobą wiele hospitalizacji i pobytów w różnych instytucjach świadczących pomoc dla osób chorujących psychicznie. Wśród wielu zachowań, które uznane zostały za symptomatyczne, było przekonanie mężczyzny, że został stworzony z brudu i jego przeznaczeniem jest stopnienie. Jego przeświadczenie sprowadzało się do odmowy wzięcia kąpieli. Psychiatrzy postrzegali zachowania pacjenta w kategoriach medycznych jako typowe dla symptomów psychotycznych. Próbowali zaradzić problemowi, koncentrując wysiłek na właściwym doborze środków farmakologicznych. Tymczasem w rozmowie z pracownikiem socjalnym pacjent ujawnił, że w przeszłości miał operację ramienia, w którym nadal czuje ból, co uniemożliwia mu wykonywanie wielu ruchów. Pracownik połączył te dwa fakty - odmowę kappieli z doświadczaniem bólu - i zaproponował korzystanie z prysznica. Jego diagnoza okazała się celna. Lekarze, którzy skupili się na poszukiwaniu wyjaśnień biomedycznych, nie mogli

${ }^{3} \mathrm{Na}$ temat różnych podejść w kwestiach związanych z zaburzeniami psychicznymi zob. A. Jarkiewicz, Społeczno-kulturowe uwarunkowania choroby psychicznej - komunikat z badań, [w:] J. Szymanowska (red.) Ewaluacja w pracy socjalnej. Badanie, ksztatcenie, praktyka, Wyd. Impuls, Kraków 2012, s. 425-435.

${ }^{4}$ K. Schock, C. Clay \& E. Cipani, Making sense of schizophrenic symptoms: Delusional statements and behavior may be functional in purpose, "Journal of Behavior Therapy and Experimental Psychiatry" 1998, 29, s. 131-141. 
przez to dostrzec w pacjencie człowieka. Trudności ludzkie, takie jak w opisanym przypadku, które naukowo zostają przekształcone w jednostki chorobowe ${ }^{5}$, ograniczają możliwości aplikacji innych podjeść, np. środowiskowych, co zmniejsza efektywność pracy i rodzi pytanie o jej sens. Szasz w wielu swoich publikacjach zwraca uwagę na zagrożenia wynikające z sprowadzania człowieka do biologii, co czyni wielu psychiatrów ${ }^{6}$. Tego typu redukcja świadczy o postępującym procesie dehumanizacji, któremu powinien się sprzeciwiać pedagog społeczny/pracownik socjalny ${ }^{7}$.

\section{Ze wspomnień praktyka - pedagoga społecznego}

Kolejny paragraf, którego podstawą są moje doświadczenia jako wolontariuszki, stażystki i pracownika, dotyczyć będzie codziennej praca pedagoga społecznego w instytucjach o profilu psychiatrycznym. Należy pamiętać, że zawarte poniżej obserwacje są subiektywną ich oceną i mam świadomość, że doświadczenia innych osób pracujących w analogicznych placówkach mogą być inne.

Praca w obszarze związanym z psychiatrią była moim marzeniem dużo wcześniej zanim wybrałam kierunek studiów. Nie byłam w stanie wyobrazić sobie siebie w roli lekarza, ponieważ, odkąd pamiętam, szeroko rozumiana praca w środowisku, daleka od kontekstu szpitalnego, a nawet stanowiąca jego totalne zaprzeczenie, pociaggała mnie. Bardziej od „uzdrowienia” w sensie medycznym interesowało mnie to, co dzieje się później z człowiekiem, kiedy przestaje już być pacjentem i musi radzić sobie w codziennym życiu wśród innych ludzi, z negatywnie kojarzącą się etykietą osoby chorej bądź zaburzonej psychicznie. Gdy usłyszałam, że na każdym oddziale istnieje „,społeczność” jako metoda pracy z grupa, że cały personel bierze udział w obchodzie i podczas zebrań dyskutuje się na temat przypadków pacjentów oraz wspólnie omawia dalsze kroki, byłam

${ }^{5}$ T. Szasz, Insanity: The idea and its consequences, John Wiley \& Sons, New York 1990, S. 167.

${ }^{6}$ T. Szasz, The myth of mental illness: Foundations of a theory of personal conduct, Harper \& Row, New York 1961; tenże, Liberation by oppression: A comparative study of slavery and psychiatry, Transaction, New Brunswick 2002; tenże, Psychiatry: The science of lies, Syracuse University Press, New York 2008.

7 Zob. D. Cohen, A critique of the use of neuroleptic drugs in psychiatry, [w:] S. Fisher \& R. G. Greenberg (red.), From placebo to panacea: Putting psychiatric drugs to the test (pp. 173-228), John Wiley, New York 1997; M. Harrow, T. H. Jobe, Factors involved in outcome and recovery in schizophrenic patients not on antipsychotic medications: A 15-year multifollow-up study, "The Journal of Nervous and Mental Disease" 2007, 195, s. 406-414; J. Hegarty, R. J. Baldessarini, M. Tohen, C. Waternaux, G. Oepen, One hundred years of schizophrenia: A metaanalysis of the outcome literature, "American Journal of Psychiatry" 1994, 151, s. 1409-1416; R. Whitaker, Anatomy of an epidemic: Magic bullets, psychiatric drugs, and the astonishing rise of mental illness in America, Crown Publishers, New York 2010. 
pewna, że szpital psychiatryczny to miejsce stworzone dla mnie jako pedagoga społecznego. Mój młodzieńczy entuzjazm szybko zderzył się z rzeczywistością, kiedy w trakcie jednego zebrania, próbując przybliżyć trudną sytuację życiową jednego z pacjentów, która według mnie mogła mieć istotne znaczenie dla jego stanu zdrowia, usłyszałam: Kwestie socjalne sq najłatwiejsze do rozwiazania, więc może w tej chwili zajmiemy się odpowiednim doborem leków ${ }^{8}$. Udział całego personelu w obchodach równie szybko przestał być elementem, który wcześniej postrzegałam jako przyczyniający się do budowania wyobrażenia o nas jako jednym zespole. Osobą prowadzącą był zawsze lekarz. Każdemu z pacjentów zadawał pytanie: Jak się Pan(i) czuje? Po krótkiej odpowiedzi szedł dalej. „Społeczność” na „moim” oddziale trwała nie dłużej niż godzinę i czasami trudno było nie odnieść wrażenia, że jej organizowanie nie ma nic wspólnego z przekonaniem o jej efektywności, ale z realizacją punktu w programie, który stanowi obowiązek zarówno dla pacjentów, jak i personelu. O niczym istotnym w trakcie jej trwania się nie mówiło. Większość pacjentów ograniczała swoją wypowiedź do sformułowania: Czuję się lepiej, lubię swojego lekarza, nie mam żadnych zastrzeżeń.

Nie inaczej było w instytucjach, które teoretycznie działały zgodnie z założeniami tzw. psychiatrii środowiskowej. Owszem pewne zadania i działania były realizowane odmiennie, na przykład wspomniana wcześniej społeczność, ale pomimo drobnych różnic nadrzędną pozycję nadal zajmował lekarz, co w znaczący sposób medykalizowało charakter pracy i ograniczało możliwości rozwoju innych podejść, w tym przede wszystkim środowiskowych czy społecznych.

\section{Psychiatria środowiskowa - przestrzeń dla pedagoga społecznego?}

Kolejną część niniejszego artykułu poświęcę prezentacji możliwości, które niesie ze sobą obecność reprezentanta podejścia społeczno-pedagogiczno-środowiskowego w miejscach pracy, które obecnie są zdominowane przez kontekst medyczny/psychiatryczny. Ma to na celu zwrócenie uwagi na wykorzystanie

\footnotetext{
${ }^{8}$ Wypowiedź lekarza psychiatry.

${ }^{9}$ Słyszałam, że na innych oddziałach „społeczność” wygląda zupełnie inaczej. Za wzór stawiany był zawsze jeden z nich, ale niestety, nie miałam okazji w nim uczestniczyć. Jako wolontariuszka natomiast brałam udział w „społeczności” w jednym ze środowiskowych domów samopomocy (ŚDS). Bardzo różniła się ona od tej, której doświadczyłam w szpitalu. Jej uczestnicy byli bardzo zaangażowani, ich opinie i sugestie miały istotny wpływ na dalszą orientację działania. W ,społeczności” w ŚDS-ie nie brał udziału lekarz, ale byli obecni psycholog, pracownik socjalny, kierownik ŚDS-u. Być może obecność psychiatry usztywnia niekiedy dyskusję. Osoby, które są bądź były pacjentami „psychiatrycznymi”, czują zbyt dużą zależność od niego i w związku z tym stają się powściągliwi w jego obecności. Zmiany formy kontaktu doświadczyłam nie raz. Pacjent, z osoby żartującej, czującej się swobodnie w obecności np. pracownika socjalnego, zmieniał się bardzo, kiedy pojawiał się lekarz. Przestawał być rozluźniony, a w skrajnych przypadkach stawał niemal na baczność.
} 
potencjału i kompetencji pedagogów społecznych w ramach istniejących już struktur i podejśćc ${ }^{10}$.

Naturalnym wyborem dla pedagoga społecznego powinno być postulowanie pracy w obszarze psychiatrycznym zgodnej z ideami psychiatrii środowiskowej $^{11}$. Na uwage pedagoga społecznego zasługuje szereg założeń tego podejścia, które dają szerokie spektrum realizowania działań społeczno-pedagogicznych. $\mathrm{Na}$ pierwszy plan wysuwa się podkreślenie istoty środowiska. W psychiatrii środowiskowej głównym układem odniesienia jest środowisko, rozumiane jako pewna wspólnota czy społeczność lokalna, której potencjał, przynajmniej w początkowych założeniach, miał być skierowany na promowanie, profilaktykę i podtrzymywanie dobrej kondycji psychicznej wśród jej członków. Ten postulat, jak zauważa Wciórka ${ }^{12}$, nie udało się z pełnym powodzeniem wdrożyć w życie, czego przyczyn, wspomniany autor, upatruje m.in. w zbyt szerokim rozumieniu zakresu psychiatrii środowiskowej. Nie oznacza to jednak, że wprowadzenie do zespołu specjalisty pracy w środowisku - pedagoga społecznego - nie mogłoby skutkować powrotem do tej idei i osiągnięciem sukcesu.

Ważnym aspektem psychiatrii środowiskowej, zbieżnym z jedną z podstawowych zasad działania pedagogów społecznych, jest kładziony w niej nacisk na profilaktykę.

Ten wątek podkreśla przekonanie, że lepiej zapobiegać zaburzeniom psychicznym niż potem z wielkim nakładem wysiłku i kosztów je leczyć. Przesuwa on punkt ciężkości zadań psychiatrii na wydarzenia i okoliczności poprzedzające pojawienie się choroby, jej nawrotu lub niesprawności życiowej ${ }^{13}$.

W psychiatrii środowiskowej profilaktyka jest ukierunkowana na trzy grupy: całe społeczeństwo, osoby i rodziny zagrożone wykluczeniem z uwagi na problem choroby psychicznej, np. w okresie rekonwalescencji, oraz grupy osób i ich rodziny aktualnie doświadczające problemu choroby.

${ }^{10}$ Nieco bardziej radykalne i krytyczne podejście, odnoszące się do kwestii znaczenia i roli pedagoga społecznego w szeroko zakreślonym polu psychiatrycznym zob. A. Jarkiewicz, „Zaburzenie psychiczne” w polu działania pracownika socjalnego, „Praca Socjalna” 2016, 2, s. 52-69.

${ }^{11}$ Psychiatria środowiskowa (community psychiatry) to współczesny kierunek psychiatrii wykorzystujący lokalne środowisko w działaniach profilaktycznych, leczeniu i rehabilitacji zaburzeń psychicznych. Opiera się przede wszystkim na takich naukach, jak: psychiatria społeczna (Z. Falicki, Psychiatria społeczna, PZWL, Warszawa 1975), psychologia społeczna, socjologia zajmująca się procesami zachodzącymi w lokalnych społecznościach. W niektórych naukach, np. w socjologii, psychiatria środowiskowa zaczęła rozwijać się zupełnie niezależnie od samej psychiatrii, a czasem nawet w opozycji do niej.

12 J. Wciórka, Psychiatria środowiskowa: idea, system, metoda i tło, „Postępy Psychiatrii i Neurologii" $2000,9$.

${ }^{13}$ Tamże, s. 320. 
W stosunku do całego społeczeństwa stosowane są następujące działania profilaktyczne ${ }^{14}$ :

1) ocena potrzeb zdrowotnych, postaw i problemów mieszkańców;

2) wykrywanie grup zwiększonego ryzyka;

3) działalność szkoleniowa i konsultacyjna wobec lokalnych placówek medycznych, a także przedstawicieli zawodów niemedycznych, którzy mogą mieć istotny wpływ na losy osób dotkniętych schorzeniem psychicznym;

4) poznanie zasobów (ludzkich, organizacyjnych, lokalowych, ekonomicznych), które można byłoby wykorzystać w realizacji programów ochrony zdrowia psychicznego;

5) opracowanie planów i sposobów realizacji działań z zakresu problemów psychiatrii środowiskowej we współpracy z przedstawicielami miejscowej społeczności.

Dla osób z drugiej i trzeciej grupy, a więc rodzin zagrożonych wykluczeniem z uwagi na problem choroby psychicznej, np. w okresie rekonwalescencji, oraz dla grupy osób i ich rodzin aktualnie doświadczających problemu choroby psychiatria środowiskowa proponuje następujące działania profilaktyczne:

1) leczenie i rehabilitację przywracającą pacjentowi zdolność do życia we własnym środowisku społecznym, a także powrót do pełnionych wcześniej ról społecznych - rodzica, pracownika itp.;

2) wnikliwą i ciągłą ocenę sytuacji pacjenta w rodzinie, miejscu pracy i szerszym środowisku społecznym, przeciwdziałanie niepomyślnemu przesunięciu socjokulturowemu i izolacji społecznej chorego;

3) udzielanie doraźnej pomocy w sytuacjach kryzysowych (crisis intervention) osobom, które doświadczyły szczególnie ciężkich zdarzeń, np. choroby psychicznej $^{15}$.

Celem interwencji kryzysowej, której działania opierają się na opracowaniu strategii działania profesjonalnego i przygotowaniu „grup wsparcia”, jest niedopuszczenie do eskalacji problemu, którego jedną z konsekwencji może być zaburzenie struktury rodzinnej. Według zwolenników tego kierunku ten rodzaj pomocy ma ogromne znaczenie w procesie powrotu do zdrowia. Efektywność interwencji opiera się na założeniu, że człowiek w sytuacji uznawanej przez niego za trudną jest bardziej podatny na przyjęcie pomocy z zewnątrz i skłonny do nauki nowych sposobów radzenia sobie z problemem. Warunkiem skutecznej interwencji jest podjęcie działania bezpośrednio po sytuacji, która spowodowała kryzys

${ }^{14}$ Por. T. Stańczakowa, Psychiatria środowiska i organizacja ochrony zdrowia psychicznego, [w:] A. Bilikiewicz, W. Strzyżewski (red.), Psychiatria. Podręcznik dla studentów medycyny, PZWL, Warszawa 1992, s. 429-430; Z. Bizoń, S. Dąbrowski, B. Pietrzykowska, Psychiatria środowiskowa, [w:] S. Dąbrowski, J. Jaroszyński, S. Pużyński (red.), Psychiatria, t. 3, PZWL, Warszawa 1989, s. 363.

${ }^{15}$ Por. T. Stańczakowa, Psychiatria środowiska i organizacja ochrony zdrowia... 
(np. rodzic jedzie do szpitala, pozostali członkowie rodziny nie wiedzą, jak radzić sobie z nową sytuacją, nie wiedza, jak przekazać ten fakt dziecku, aby zminimalizować jego cierpienie, które i tak wystapi na skutek rozłąki z rodzicem). Celem interwencji kryzysowej jest nie tylko uzyskanie doraźnej poprawy stanu psychicznego chorego, lecz także złagodzenie napięć w jego środowisku społecznym. Gdy wymagane jest dalsze leczenie, w proces ten należy włączyć osoby znaczące.

Niezwykle ważnym elementem psychiatrii środowiskowej jest system oparcia społecznego, którego szczególnym adresatem są osoby przewlekle chorujące psychicznie. W psychiatrii środowiskowej wyróżnia się trzy rodzaje systemów oparcia:

1. Naturalny, stanowiący sieć kontaktów społecznych, od których jednostka uzyskuje pomoc w codziennych trudnościach, a także pomoc i wsparcie w szczególnie trudnych dla niej sytuacjach życiowych. W skład naturalnego wsparcia wchodzi przede wszystkim rodzina, przyjaciele, dalsi krewni itp. Praktycznie każda osoba z niego korzysta. Brak naturalnego wsparcia źle rokuje w leczeniu schizofrenii, jak również w podeszłym wieku i przy zaburzeniach psychicznych - depresjach, nerwicach.

2. System oparcia $\mathrm{w}$ ramach instytucji. Niektóre wspólnoty religijne moga tworzyć skuteczny system oparcia. Pozytywne rezultaty dostrzegalne są też w działalności takich instytucji, jak: stowarzyszenia społeczne, grupy samopomocy, kluby itp. W psychiatrii środowiskowej szczególnie ważną rolę odgrywają m.in. stowarzyszenia pacjentów i ich rodzin. W wielu krajach takie grupy stanowią skuteczną siłę nacisku, która podnosi efektywność świadczeń zdrowotnych. Osoby chorujące często same organizują własny system świadczeń zdrowotnych, oświatowych i zawodowych.

3. Środowiskowy system oparcia - instytucja plus osoby z rodzin dotkniętych problemem i społeczności lokalne - stanowi zorganizowaną działalność osób i instytucji, które są zobowiązane (bądź chcą pomóc) do udzielania pomocy osobom cierpiącym na przewlekłe, prowadzące do obniżenia sprawności w funkcjonowaniu społecznym choroby i zaburzenia psychiczne ${ }^{16}$.

Przyjazne dla pedagoga społecznego założenia psychiatrii środowiskowej odnoszą się do współdzielenia odpowiedzialności, co realizowane jest poprzez podkreślanie idei partnerstwa nie tylko w relacji lekarz-pacjent, lecz także z osobami współtworzącymi zespół, a które dysponują różnym przygotowaniem zawodowym. „Sposobem realizowania nowych zasad kształtujących te relacje (np. demokracji, permisywności, partnerstwa, przyzwalania, zgody, realizmu, wspólnoty) była społeczność terapeutyczna i wielkie hasło odnowy postaw zawodowych"17. Ponadto wielostronność świadczeń, czyli realizacja zadań związanych

\footnotetext{
${ }^{16}$ Tamże, s. 429-450.

${ }^{17}$ J. Wciórka, Psychiatria środowiskowa: idea, system..., s. 321.
} 
nie tylko z somatycznymi czy psychicznymi aspektami chorowania, lecz także społecznymi, których znaczenie było często marginalizowane przez przedstawicieli profesji medycznych. Wielokierunkowość oddziaływań podnosi rangę i istotę metod środowiskowych, których ekspertem jest pedagog społeczny. Psychiatria środowiskowa kładzie nacisk na zintegrowany model rozwiązywania problemów zdrowotnych, co daje szerokie pole do pracy zespołowej i współpracy między osobami z różnymi kompetencjami i różnym przygotowaniem teoretycznym.

Wątki środowiskowe, silnie eksponowane w psychiatrii środowiskowej, zwane socjocentryzmem, podkreślają ich rolę i znaczenie dla powstawania, przebiegu i dalszego losu osoby chorującej. Kontekst społeczny stanowi podstawowy układ odniesienia teoretycznego i praktycznego, a środowiskowe metody oddziaływania są integralną częścią programu leczenia. W zakresie tego działania rola pedagoga społecznego wydaje się oczywista. Pedagog społeczny posiadający specjalistyczne wykształcenie w kierunku diagnozowania uwarunkowań społecznych, w ramach tzw. diagnozy społecznej, jako członek zespołu terapeutycznego mógłby znacząco przyczynić się do zwiększenia efektywności pracy. Praca w środowisku jest dla pedagoga społecznego naturalnym polem praktyki. W toku studiów nabywa on wiedzę i umiejętności potrzebne do organizacji tego rodzaju działania. Wiele badań wskazuje, że pomijanie społecznych uwarunkowań sprawia, że psychiatria z proponowanym oddziaływaniem stricte medycznym znacząco zmniejsza skuteczność leczenia ${ }^{18}$. Szczególna wrażliwość pedagoga społecznego właśnie na ten kontekst uzasadnia jego obecność w zespole terapeutycznym.

\section{Wyzwania w obszarze psychiatrii środowiskowej}

W założeniach i proponowanych metodach pracy psychiatria środowiskowa wydaje się zbieżna z pedagogiką społeczną i tworząca przyjazną przestrzeń dla jej rozwoju oraz możliwości działania dla jej reprezentantów. Można pokusić się o stwierdzenie, że jej podwaliny były kładzione przez osoby z wrażliwością społeczno-pedagogiczna, bliską pedagogom społecznym. Ta bliskość spowodowała, że dla wielu reprezentantów tego kierunku, chcących związać swoją profesjonalną biografię $\mathrm{z}$ działalnością $\mathrm{w}$ obszarze psychiatrycznym, psychiatria środowiskowa może wydać się atrakcyjnym rozwiązaniem. To, że podejście to obecne jest w strukturach pomocy psychiatrycznej, nie oznacza jednak, że przyszli praktycy nie napotkają tu pewnych przeszkód czy wyzwań, których istnienia pedagodzy powinni być świadomi. Zostaną tu omówione niektóre z nich.

Pomimo sporego zainteresowania tym podejściem przez reprezentantów profesji medycznych i niemedycznych obecnie trudno wskazać w Polsce

${ }^{18}$ F. M. Stark, Does social psychiatry have a future?, "International Journal of Mental Health" 1998, 26, s. 3-26. 
ośrodki, które w pełni rozwinęły i wdrożyły w życie postulaty psychiatrii środowiskowej. Instytucje, które już na poziomie nazwy sugerują preferowany styl pracy, często w praktyce gubią istotę tego podejścia na rzecz medycznego. Jest to widoczne na wielu płaszczyznach, np. języka, orientacji działania i struktury ważności oddziaływań. Praca zespołowa nadal stanowi duże wyzwanie, szczególnie w obszarze namysłu i orientowania działania, które w chwili obecnej mocno uprzywilejowuje leczenie farmakologiczne, spychając kontekst społeczny na margines rozważań. Przedstawiciele innych specjalizacji niż medyczne dobrowolnie oddają ten obszar w ręce psychiatrów jako osób decydujących. Umacniają w ten sposób ich pozycję i przyczyniają się do odtwarzania „starego” porządku. Świadczy to o głębokim zakorzenieniu i ugruntowaniu perspektywy medycznej (psychiatrycznej) w naszym kontekście kulturowym Przestaje ona podlegać dyskusji i jest przyjmowana na zasadzie oczywistości jako jedyna. Medyczne teorie, w scenerii polskiej, ale również szerzej, wywalczyły monopol na rozstrzyganie w kwestiach związanych z chorobami i zaburzeniami psychicznymi. Obecnie perspektywa psychiatryczna zajmuje uprzywilejowaną pozycję w tym przedmiocie. Narzucony przez nią sposób definiowania skutecznie przeniknął do myślenia nie tylko w wąskim gronie profesjonalistów, lecz przede wszystkim do myślenia społecznego. Można tego doświadczyć chociażby w rozmowach potocznych, jak również śledząc i analizując dyskurs medialny oraz sposób, w jaki mówi się o tym problemie. Konsekwencją tego jest praca zespołu pod kierownictwem psychiatrii, co ukierunkowuje działania w kierunku medycznym.

Opisane powyżej czynniki silnie oddziałują na funkcjonowanie instytucji rządowych. Niestety, jak pisze Wciórka ,psychiatria środowiskowa znajduje niewielkie zainteresowanie i uznanie u politycznych decydentów i administratorów ubezpieczeń zdrowotnych"19. Jak zauważa Frazer, Westhuis, Daley, Phillips ${ }^{20}$ „dominacja biomedycznego modelu w serwisie usług w obszarze zdrowia psychicznego permanentnie przenika prawne, rządowe i finansowe systemy, które odpowiedzialne są za ich wspieranie ${ }^{21}$ ". Konsekwencją tego jest podawanie, na wczesnym etapie koncepcyjnym, w watpliwość pomysłów i podejść, które nie eksponują perspektywy medycznej.

Wspomniane słabości współczesnej psychiatrii środowiskowej są elementem bardziej złożonego zjawiska, które Conrad ${ }^{22}$ nazwał „,medykalizacją”. Termin

${ }^{19}$ J. Wciórka, Psychiatria środowiskowa: idea, system..., s. 329.

${ }^{20}$ P. Frazer, D. Westhuis, J. G. Daley \& I. Phillips, How clinical social workers are using the DSM-IV: A national study, "Social Work in Mental Health" 2009, 7, s. 325-339.

${ }^{21}$ Thumaczenie własne.

${ }^{22}$ P. Conrad, Medicalization and social control, "Annual Review of Sociology" 1992, 18, s. 209-232; tenże, The medicalization of society: On the transformation of human conditions into treatable disorders, MD: Johns Hopkins University Press, Baltimore 2007. 
„medykalizacja ${ }^{23}$ ” (medicalization) opisuje ,proces, poprzez który niemedyczne problemy są definiowane i traktowane tak, jakby były problemami medycznymi, co uwidacznia się na poziomie stosowanego języka ich opisu, który odnosi się zazwyczaj do chorób i zaburzeń2 ${ }^{24}$.

\section{Zakończenie}

W artykule starałam się opisać możliwości rozwoju i działania pedagoga społecznego w zakresie problematyki zaburzeń psychicznych. Prezentowane podejście środowiskowe w ramach koncepcji psychiatrii środowiskowej jest zaledwie jednym z wielu, otwierającym szerokie spektrum dla aktywności społeczno-pedagogicznej. Bez tego trudno sobie wyobrazić profesjonalizację działań pedagogów społecznych w tym obszarze. Zapewnienie przestrzeni do urzeczywistnienia działań społeczno-pedagogicznych poprzedzonych rzetelną diagnozą społeczną daje sposobność do refleksji, która jest niezbędna do poszerzenia wiedzy i zintensyfikowania pracy nad rozwojem teorii społecznych związanych z przedstawianą tematyką. Tak rozumiany rozwój nauki jest zbieżny z samą definicją pedagogiki społecznej, ponieważ podkreśla wymiar praktyczny tej (sub)dyscypliny i podkreśla znaczenie tzw. badania w działaniu.

Odmienną kwestią, która może mieć korzystny wpływ na zwiększenie znaczenia działań o charakterze społeczno-pedagogicznym, jest praca nad rozpoznawalnością zawodu pedagoga społecznego w szerszym kontekście instytucjonalno-społecznym. W tej sytuacji sprawą priorytetową jest więc podjęcie starań o wyodrębnienie autonomicznego stanowiska dla pedagoga społecznego.

\section{Bibliografia}

Bizoń Z., Dąbrowski S., Pietrzykowska B., Psychiatria środowiskowa, [w:] S. Dąbrowski, J. Jaroszyński, S. Pużyński (red.), Psychiatria, t. 3, PZWL, Warszawa 1989.

Cohen D., A critique of the use of neuroleptic drugs in psychiatry, [w:] S. Fisher \& R. G. Greenberg (red.), From placebo to panacea: Putting psychiatric drugs to the test (pp. 173-228), John Wiley, New York 1997.

Conrad P., Medicalization and social control, "Annual Review of Sociology" 1992, 18, s. 209-232.

Conrad P., The medicalization of society: On the transformation of human conditions into treatable disorders, MD: Johns Hopkins University Press, Baltimore 2007.

Falicki Z., Psychiatria społeczna, PZWL, Warszawa 1975.

Frazer P., Westhuis D., Daley J. G. \& Phillips I., How clinical social workers are using the DSM-IV: A national study, "Social Work in Mental Health" 2009, 7, s. 325-339.

${ }^{23}$ Szerzej na temat „medykalizacji pracy socjalnej” w: A. Jarkiewicz, Medykalizacja pracy socjalnej w obszarze działania z osobami zaburzonymi psychicznie, „Annales Universitatis Mariae Curie-Skłodowska. Sectio J - Paedagogia-Psychologia” (w druku).

${ }^{24}$ P. Conrad, The medicalization of society..., s. 14 (tłumaczenie własne). 
Harrow M., Jobe T. H., Factors involved in outcome and recovery in schizophrenic patients not on antipsychotic medications: A 15-year multifollow-up study, "The Journal of Nervous and Mental Disease" 2007, 195, s. 406-414.

Hegarty J., Baldessarini R. J., Tohen M., Waternaux C., Oepen G., One hundred years of schizophrenia: A meta-analysis of the outcome literature, "American Journal of Psychiatry" 1994, 151, s. 1409-1416.

Jankowski K., Od psychiatrii biologicznej do humanistycznej, PIW, Warszawa 1975.

Jarkiewicz A., Medykalizacja pracy socjalnej w obszarze działania z osobami zaburzonymi psychicznie, „Annales Universitatis Mariae Curie-Skłodowska. Sectio J - Paedagogia-Psychologia" (w druku).

Jarkiewicz A., Społeczno-kulturowe uwarunkowania choroby psychicznej - komunikat z badań, [w:] J. Szymanowska (red.), Ewaluacja w pracy socjalnej. Badanie, ksztatcenie, praktyka, Wyd. Impuls, Kraków 2012.

Jarkiewicz A., ,Zaburzenie psychiczne” w polu działania pracownika socjalnego, „Praca Socjalna” 2016, 2.

Jaroszyński J., Niektóre wspótczesne kierunki psychiatrii, [w:] S. Dąbrowski, J. Jaroszyński, S. Pużyński (red.), Psychiatria, PZWL, Warszawa 1989.

Schock K., Clay C. \& Cipani E., Making sense of schizophrenic symptoms: Delusional statements and behavior may be functional in purpose, "Journal of Behavior Therapy and Experimental Psychiatry" 1998, 29, s. 131-141.

Stańczakowa T., Psychiatria środowiska i organizacja ochrony zdrowia psychicznego, [w:] A. Bilikiewicz, W. Strzyżewski (red.), Psychiatria. Podręcznik dla studentów medycyny, PZWL, Warszawa 1992.

Stark F. M., Does social psychiatry have a future?, "International Journal of Mental Health" 1998, 26, s. 3-26.

Szasz T., Insanity: The idea and its consequences, John Wiley \& Sons, New York 1990.

Szasz T., Liberation by oppression: A comparative study of slavery and psychiatry, Transaction, New Brunswick 2002.

Szasz T., Psychiatry: The science of lies, Syracuse University Press, New York 2008.

Szasz T., The myth of mental illness: Foundations of a theory of personal conduct, Harper \& Row, New York 1961.

Wciórka J., Psychiatria środowiskowa: idea, system, metoda i tło, „Postępy Psychiatrii i Neurologii” 2000, 9.

Whitaker R., Anatomy of an epidemic: Magic bullets, psychiatric drugs, and the astonishing rise of mental illness in America, Crown Publishers, New York 2010. 